\title{
INNOVATIVE USE OF QUALITY MANAGEMENT METHODS FOR PRODUCT IMPROVEMENT
}

\author{
Katarzyna MIDOR \\ Silesian University of Technology \\ Jozef ŽARNOVSKÝ \\ Slovak University of Agriculture in Nitra
}

\begin{abstract}
:
Organisations constantly look for new, innovative solutions and methods which could be used to improve their efficiency and increase the quality of their products. Identifying the causes for returns is an important issue for modern companies, as returns are the cause for the increase in production costs and, most importantly, the loss of credibility in the eyes of the client. Therefore, for the company to be able to sustain or strengthen its position on the market, it has to follow the rules of quality management. Especially important is the rule of constant improvement. This rule is primarily connected with preventing errors and defects from occurring at all the stages of the production process. To achieve that, one must, among other things, use quality management tools. The article presents an analysis of causes for returns of a vibrating screen produced by a company which manufactures machinery and equipment for the extractive industry, using quality management tools such as the Ishikawa diagram and Pareto analysis. The analysis allowed for the identification of the causes of client returns which could not be previously identified, and proposing solutions for them.
\end{abstract}

Key words: innovation, improvement, quality management, quality management tools, product

\section{INTRODUCTION}

Current market is dynamic, which requires companies to be competitive, while the pervasive globalisation and fast technological development forces them to improve their products and processes. Product improvement requires systematic, planned and fact-based action.

In order to surpass strong competition, companies need to offer their clients products which meet their quality requirements. Therefore, quality becomes the priority for a modern, developing company with long-term strategies. To ensure a high standard of products, companies should introduce innovative methods, which have had the desired effect in other industries. The issue of identifying shortcomings, especially the causes for returns, is important for companies, as they increase production costs and, most importantly lead to the loss of credibility in the eyes of the client. Both those situations are highly undesirable for a company $[2,4,6]$. That is why, in order to increase efficiency, managers use various techniques at all stages of the production process, from planning to delivery to the client. Many improvement tools and methods are used in the literature and practice of quality management $[1,3,5,6,7,8$, 9].

The article presents the use of well-known tools such as Pareto and Ishikawa for identifying the causes for returns of a vibrating screen, and proposed improvement measures based on the results, which eliminate the possibility of those defects occurring in the future.

\section{IDENTIFICATION OF THE STUDY SUBJECT AND RESEARCH PROBLEM}

A vibrating screen is a device used for classifying grain materials in dry and wet processes, as well as the processes of desiccation, desludging and flushing. Their principle of operation consists of inducing vibration of their sieve by means of an engine, which results in the material which is placed on the sieve being separated into particular fractions. These devices are produced by a manufacturer of machinery and equipment for the underground and opencast extractive industry located in Silesia.

The manufacturing of a vibrating screen is a complex process which consists of a number of various technological, transport, control and storage operations. These operations are carried out based on project documentation drawn beforehand by constructors and technologists [10].

In the years 2014-2015 a number of returns have been observed in the company, which consisted of faults and defects of devices already used by the client - Table 1 .

These defects occurred during the operation of the device. This type of defects is the most costly, as it very often entails, among others, the need to send a servicing team to the site where the device is being used. Additionally, if a serious problem is detected, it is oftentimes necessary to dismantle the device or one of its parts and transport it to the production hall in order to remove the defect. 
Juxtaposition of defects discovered during the operation of a vibrating screen

\begin{tabular}{|c|c|c|}
\hline No. & Type of defect & Amount [pcs] \\
\hline 1 & Sieve rusting & 28 \\
\hline 2 & Drive beam fracture & 4 \\
\hline 3 & Supporting beam fracture & 3 \\
\hline 4 & Sieve brim fracture & 3 \\
\hline 5 & Efficiency below expectations & 2 \\
\hline 6 & Sieve spring fracture & 5 \\
\hline 7 & Drive breakdown & 15 \\
\hline 8 & Engine breakdown & 7 \\
\hline 9 & Other & 4 \\
\hline
\end{tabular}

Source: Own elaboration based on the company's documentation [10].

Table 2

Results of the Pareto-Lorenz analysis for the defects occurring during the device's operation

\begin{tabular}{|c|c|c|c|c|c|}
\hline No. & $\begin{array}{c}\text { Type } \\
\text { of defect }\end{array}$ & $\begin{array}{l}\text { Amount } \\
\text { [pcs] }\end{array}$ & $\begin{array}{c}\text { Percentage } \\
{[\%]}\end{array}$ & $\begin{array}{c}\text { Cumulative } \\
\text { percentage [\%] }\end{array}$ & Group \\
\hline 1 & Sieve rusting & 28 & 39.44 & 39.44 & A \\
\hline 2 & Drive breakdown & 15 & 21.13 & 60.56 & A \\
\hline 3 & Engine breakdown & 7 & 9.86 & 70.42 & $A$ \\
\hline 4 & Sieve spring fracture & 5 & 7.04 & 77.46 & $A$ \\
\hline 5 & Drive beam fracture & 4 & 5.63 & 83.10 & B \\
\hline 6 & Other & 4 & 5.63 & 88.73 & B \\
\hline 7 & Supporting beam fracture & 3 & 4.23 & 92.96 & B \\
\hline 8 & Sieve brim fracture & 3 & 4.23 & 97.18 & C \\
\hline 9 & Efficiency below expectations & 2 & 2.82 & 100 & C \\
\hline
\end{tabular}

\section{USING THE PARETO-LORENZ ANALYSIS TO IDENTIFY THE FOREMOST CAUSES FOR RETURNS}

In accordance with the Pareto-Lorenz analysis methodology, the defects identified in Table 1 were put in decreasing order, their cumulative percentage calculated and qualified into one of the groups - A, B or C. Group A contains defects which constitute $80 \%$ of the causes of the problem, group B are defects which cause $15 \%$ of the returns and group $C$ consists of defects which cause $5 \%$ of all the nonconformities. Table 2 presents the results of the analysis.

An analysis of the data from Table 2 shows that 4 defects from the A group are the most important causes. According to the Pareto analysis all the defects in group $A$ should be subjected to a thorough analysis first, followed by those in groups B and C. However, for the needs of this elaboration, only the first defect - "Sieve rusting" - which has the highest percentage share in all the identified returns will be subjected to analysis.

\section{ANALYSIS OF THE CAUSES FOR SIEVE RUSTING - ISHIKA- WA DIAGRAM}

Having identified the main return cause, I then used the Ishikawa diagram, which allows for the identification of causes of the problem in areas such as the human factor, method, machine (tool), material and management. Table 3 presents the analysis of the cause along with its description.

\section{IMPROVING THE VIBRATING SCREEN PRODUCTION PRO- CESS}

The identified causes of sieve rusting which have been presented in Table 3 were subjected to further analysis via brainstorming with a team of experts. The aim was to select the most favourable solutions, which would increase the efficiency of the process and reduce the costs connected with warranty servicing. Based on the ideas, the team selected a few solutions which allowed us to streamline the production process of the screen and thereby eliminate the causes of returns connected with sieve rusting. The proposed solutions have been presented in Table 4.

Improvement solutions to the process of sieve painting consist in, among other things, including information about the type and thickness of the individual layers of coating along with the symbols of the paints used in the assembly manual. This will make it possible to get rid of the problem of layers "clashing" due to accidentally choosing the wrong paints dedicated for the separate layers. It was also proposed that a control operation be introduced after putting on each layer, which would encompass measuring the thickness of the layer with a gauge. This will result in the sieve being painted more thoroughly, in accordance with the right technology, which will prolong the life of anticorrosive coatings, thus significantly reducing the number of returns it causes. 
Table 3

Analysis of the Ishikawa diagram for the sieve rusting problem

\begin{tabular}{cc}
\hline Area & Cause \\
\hline
\end{tabular}

Painting hose too short

Tool

Bad condition of the painting nozzles

Bad condition of the painting aggregate

Using paints past their expiration date

Material

Bad paint quality

Bad choice of painting nozzles

Method

Bad choice of painting set

Wrongly determined anti-corrosiveness class of the working environment of the device

Not cleaning the aggregate and nozzles after previous painting

Using wrong proportions when mixing two-component paints

Taking the wrong paints which make up

Human the painting set

Not measuring the thickness of the coating

Inaccuracy when performing

a technological operation

Not following the instructions pertaining to the technology of applying layers

Too short a time from passing on the workshop documentation to device shipment

\section{Description}

This cause can lead to problems connected with accurately painting the sieve of the sifter. Using too short a painting hose can hinder the painter's work, which will result in the screen being improperly painted and, consequently, rusting.

If the painting nozzles are in bad condition, they spread the paint coating unevenly, which can result in the coating being too thin on some of the sieve's elements.

this cause can lead to an insufficient amount of paint being pumped as well as an uneven stream, which will result in the sieve being improperly painted and, consequently, rusting.

If one of the components of two-component paints is past its expiration date, there is a risk of the mixing process not going according to the technology and the mix not reaching the expected properties. This problem can result in decreased durability time of the coating, thus causing the rusting to setin earlier.

In this case the fault lies with the supplier. There is a risk that paints supplied by contractors might not meet the requirements guaranteed in the technological sheets.

A bad choice of painting nozzles for the anti-corrosion system used can lead to the machine not being able to feed a sufficient amount of paint mixture. There can also occur a problem with a badly matched nozzle spreading the stream of paint too narrowly or too widely, which makes it impossible to reach the right thickness of the paint coating.

Bad choice of the elements of the painting set can lead to the individual layers of the paint coating to "clash" with each other and not bind properly. This problem can be the cause of premature rusting of the sieve.

It is a cause which occurs during the designing and construction stages. If the environment's anti-corrosiveness class is wrongly determined in the initial assumptions then, if it turns out to be higher in reality, there is a high risk of the sieve rusting prematurely.

If the elements of the painting aggregate are not thoroughly washed and cleaned after painting, there is a risk of the paints "biting" into the residue of the old ones left in the aggregate during the next painting. This can lead to a decrease in the durability time of the anti-corrosive coating.

If the painter wrongly selects the proportions of two-component paints, there is a possibility of them not reaching their expected properties, which would lead to a decrease in the durability time of the individual coatings.

This cause can lead to the surface paint not catching on to the primer paint, which significantly shortens the durability time of the anti-corrosive coating.

This cause can affect the improper thickness of the anti-corrosive coating. If the layer of paint is too thin, the sieve might start rusting faster.

If a paint shop worker improperly sandblasts the sieve elements or does not put in enough effort into applying the right amount of paint in layers on all the elements of the screen, there is a risk that the rusting process will set on earlier.

If the times of drying and hardening of the individual layers of the paint coating are not observed, there is a risk that the layers might mix together, thus losing some of their anti-corrosive properties. The main factor in this cause is the rush in painting the steel elements of the sieve. It stems from bad organisation of the management staff, who do not set aside enough time for performing all the technological operations. 


\begin{tabular}{|c|c|}
\hline Area & Improvement measures \\
\hline \multirow[t]{3}{*}{ Tool } & 1. Buying a $30 \mathrm{~m}$ painting hose. \\
\hline & 2. Buying a new set of painting nozzles dedicated for different types and thicknesses of layers. \\
\hline & 3. Hiring a maintenance employee responsible for inspections, servicing and the condition of the machine park. \\
\hline \multirow[t]{2}{*}{ Material } & $\begin{array}{l}\text { 1. Introducing increased control connected with delivery reception. Instructing the warehouse person to check the } \\
\text { expiry date of the received paints. }\end{array}$ \\
\hline & 2. Buying painting sets from other suppliers in order to verify their quality and choose the best contractor. \\
\hline \multirow[t]{2}{*}{ Method } & $\begin{array}{l}\text { 1. Unifying the types of painting sets used. Choosing one solution (system) will eliminate the problem of "slashing" } \\
\text { layers as well as facilitate the choice of nozzles for the individual sets. }\end{array}$ \\
\hline & $\begin{array}{l}\text { 2. Increasing control in the design department by checking the designs of machines by the technical director before } \\
\text { issuing workshop documentation. }\end{array}$ \\
\hline \multirow[t]{2}{*}{ Human } & $\begin{array}{l}\text { 1. Introducing training of new employees on sieve painting by an experienced painter. } \\
\text { 2. Introducing coating thickness control after painting. }\end{array}$ \\
\hline & 4. Attaching information about the thickness and type of coatings along with paint symbols to the assembly manual. \\
\hline Management & $\begin{array}{l}\text { 1. Increasing the production time of the devices in order to attain long enough time periods for completing the indi- } \\
\text { vidual technological operations. }\end{array}$ \\
\hline
\end{tabular}

\section{CONCLUSIONS}

If they wish to stay competitive in the market, companies cannot afford not to take measures to improve their products and processes. One of the ways for such improvement is introducing innovations, which have already proven effective in other branches of the industry.

Such an innovation can be the use of simple quality management tools which do not require large resources while quickly providing solutions for the problems at hand .The example presented in this article shows that simple tools such as Pareto and Ishikawa make it possible to quickly identify the causes of returns, which in turn allows us to take measures to eliminate them, reducing production costs and increasing the client's satisfaction.

\section{This article was prepared within the statutory research titled "Production engineering methods and tools for development of smart specializations", work symbol 13/030/BK_16/0024 performed at Silesia University of Technology, Institute of Production Engineering.}

\section{REFERENCES}

[1] J.J. Dahlgaard, K. Kristensen and G.K. Kanji, Podstawy zarzqdzania jakościq, Warszawa: Wydawnictwo Naukowe PWN, 2002.

[2] B. Gajdzik and J. Sitko, "An analysis of the causes of complaints about steel sheets in metallurgical product quality management systems", Metalurgija, vol. 53(1), 2014, pp. 135-138.

[3] A. Hamrol, Zarzqdzanie Jakościq z przykładami, Warszawa: Wydawnictwo Naukowe PWN, 2008.

[4] M.J. Ligarski, "Problem identification method in certified quality management systems", Quality \& Quantity, vol. 46(1), 2012, pp. 315-321.

[5] K. Midor, "An analysis of the causes of product defects using quality management tools", Management Systems in Production Engineering, vol. 4(16), 2014. pp. 162-167.

[6] M. Molenda, "Effectiveness of planning internal audits of the quality system", Zeszyty Naukowe Akademii Morskiej w Szczecinie, no. 32, z. 1, 2012, pp. 48-54.

[7] B. Szczęśniak, M. Zasadzień and $Ł$. Wapienik, „Zastosowanie analizy Pareto oraz diagramu Ishikawy do analizy przyczyn odrzutów w procesie produkcji silników elektrycznych", Zeszyty Naukowe Politechniki Ślq̨skiej (s. Organizacja i Zarzqdzanie), z. 63a, 2012, pp. 125-148.

[8] M. Zasadzień, "Using the Pareto diagram and FMEA (Failure Mode and Effects Analysis) to identify key defects in a product", Management Systems in Production Engineering, no 4, 2014, pp. 153-156.

[9] E. Kardas, "The assessment of quality of products using selected quality instruments", Production Engineering Archives, vol. 10, no. 1, 2016, pp. 5-8.

[10] G. Klimasara, „Analiza i doskonalenie procesu produkcyjnego wybranego produktu w przedsiębiorstwie Demetrix Sp. z o.o.", Politechnika Śląska, Wydział Organizacji i Zarządzania, Zabrze, 2016.
Artykuł w polskiej wersji językowej dostępny na stronie internetowej czasopisma.
The article in Polish language version available on the website of the journal 